\title{
LEGISLASI PENDEWASAAN USIA PERKAWINAN ALTERNATIF PERPSEKTIF HUKUM ADAT DALAM PEMBANGUNAN HUKUM NASIONAL
}

\author{
Miftahus Sholehudin \\ Dosen Fakultas Syariah UIN Maulana Malik Ibrahim Malang \\ mifudin@syariah.uin-malang.ac.id
}

\begin{abstract}
There is no desire for prospective brides in marriage to be an intrinsic requirement that becomes very important but does not determine the position of conditions in marriage. The national legal regulations contained in legislation also have very complicated variations in determining a person's maturity level depending on the role and needs of the child as a legal subject. Customary law as a law that develops together with developing communities has ownership with various kinds. This becomes a very important capital for legislators in communicating between customary law and the development of national law. The end result of collaboration is expected to be able to bridge a variety of norm mismatches with the ideal conditions reported by the community. This paper seeks to present a pattern of communication of national law with customary law in the formation of national law so that it is interwoven
\end{abstract}

Keywords : legislation, marriage age, customary law, national development

\begin{abstract}
Abstrak, Unsur kedewasaan bagi calon mempelai dalam perkawinan menjadi syarat intrinsik yang menjadi sangat penting namun tidak menempati posisi syarat sah dalam perkawinan. Konfigurasi hukum nasional yang tertuang dalam peraturan perundang-undangan juga memiliki variasi yang sangat kompleks dalam menentukan tingkat kedewasaan seseorang tergantung pada peran serta kebutuhan anak sebagai subjek hukum. Hukum adat sebagai hukum yang berkembang bersama dengan perkembangan masyarakat telah memiliki penentuan dengan berbagai ragamnya. Hal ini menjadi modal yang sangat penting bagi legislator dalam mengkomunikasikan antara hukum adat dengan pembangunan hukum nasional. Hasil akhir dari kolaborasi inilah yang diharapkan dapat menjembatani berbagai ketidak sesuaian norma dengan kondisi ideal yang dicitakan oleh masyarakat. Tulisan ini hendak menyuguhkan pola komunikasi hukum nasional dengan hukum adat dalam pembentukan norma hukum nasional sehingga terjalin ko-eksistens antara keduanya.

Kata kunci : legislasi, usia perkawinan, hukum adat, pembangunan nasional
\end{abstract}

\section{Pendahuluan}

Terminologi Dewasa dalam dunia sosial merupakan indikator yang sangat sulit di kalkulasikan dalam bentuk angka atau umur seseorang. Lebih jauh lagi para ilmuwan dalam bidang sosiologi menyebutkan bahwa dewasa merupakan sebuah paradoks yang dilekatkan bagi masa menengah kehidupan manusia.

Adulthood holds a paradoxical position in sociology. It is a central category insofar as it provides the unarticulated background to a majority of social enquiries, but it is 
largely defined by default as the taken-for-granted status of the social actor and the middle stage of life .

Namun demikian, dalam hubunganya dengan perkawinan, kedewasaan menjadi unsur penting dalam menentukan telah mampu atau belum dalam menjalankan fungsifungsi keluarga. Banyak faktor yang dilekatkan dalam menentukan kedewasaaan seseorang baik ditinjau dari faktor sosial, ekonomi, psikologi serta berbagai faktor lainnya ${ }^{2}$.

Unicef sebagai lembaga yang konsen dalam perlindungan terhadap anak melaporkan, bahwa lebih dari 700 Juta penduduk dunia melakukan pernikahan pada usia sebelum 15 tahun. Bahkan Indonesia menempati posisi teratas dalam tingginya perkawinan anak sebagaimana kutipan berikut.

Over 700 million women alive today were once child brides, and one in three of these girls married before the age of 15. Indonesia is part of the top countries with the highest absolute numbers of child marriage, the child marriage burden, ranking seventh globally. In 2012, 1,348,886 girls married before the age of 18, equal to 3,695 girls per day. Of these girls, 292,663 married before 16 and 110,198 before $15^{3}$.

Ketentuan unsur dewasa dalam perkawinan sangat lekat dengan problem perlindungan anak. Namun, meski isu perkawinan anak merupakan masalah penting di Indonesia, praktik perkawinan anak memiliki dimensi yang sangat beragam baik terkait faktor geografis, budaya, dan agama ${ }^{4}$. Menentukan dan merubah peraturan perundangundangan yang berlaku tentang batas usia kawin-pun mengalami tantangan dan problem yang sangat pelik baik dari faktor politik, sosial bahkan faktor pemhaman terhadap agama.

Secara empiris, adat, kepercayaan, serta agama memiliki korelasi yang sangat erat dalam praktik terjadinya perkawinan anak di Indonesia. Misalnya, di beberapa daerah di Indonesia, adat-istiadat setempat banyak menyebabkan anak perempuan menikah dengan pria yang jauh lebih tua. Begitu juga keyakinan dan pemahaman agama juga memiliki andil dalam terjadinya pernikahan anak dimana menikah dipersepsikan sebagai ibadah yang harus disegerakan.

Beberapa riset menunjukkan, bahwa beberapa remaja memilih untuk menikah atas keinginan orang tua mereka karena stigma tentang perempuan dewasa yang tidak menikah, kekhawatiran akan kehamilan atau pengenalan seks pranikah, dan kemiskinan ${ }^{5}$. Oleh karena itu, praktik perkawinan anak di Indonesia bersifat kompleks dan mencerminkan keragaman nilai dan norma sosial di Indonesia. 90 persen permintaan

\footnotetext{
${ }^{1}$ Harry Blatterer, 'Contemporary Adulthood, Reconceptualizing an Uncontested Category', Sage Journal: Current Sociology, Volume 55, Issue 6, 2007

${ }^{2}$ Chuzaimah T. Yanggo, Problematika Hukum Islam Kontemporer (Jakarta: Lembaga Studi Islam dan Kemasyarakatan , 2004). 65

${ }^{3}$ Unicef Indonesia, Child Marriage in Indonesia (Jakarta: unicef media center, 2016), pp. 1-7.

${ }^{4}$ Subdirektorat Statistik Rumah Tangga, Kemajuan yang Tertunda: Analisis Data Perkawinan Anak di Indonesia (Jakarta: Badan Pusat Satistik Indonesia, 2016). Hal 19

${ }^{5}$ Mark Evenhuis and Jennifer Burn, Just Married, Just a Child: Child marriage in the IndoPacific region (Melbourne: Plan International Australia, 2014). P. 26
} 
dispensasi yang diajukan ke pengadilan diterima dengan jumlah permohonan telah meningkat dalam beberapa tahun terakhir.

Praktik perkawinan di bawah umur dapat terjadi baik kedua pasangan adalah mereka yang masih masuk dalam kategori anak, atau salah satu dari keduanya yang masih berusia anak ${ }^{6}$. Dengan kata lain, perkawinan di bawah umur merupakan perkawinan yang di lakukan oleh pasangan yang menurut hukum positif masih belum cukup untuk melaksanakan perkawinan.

Berdasarkan Data Badan Pusat Statistik Tahun 2017, angka prevalensi perkawinan anak sudah menunjukkan angka yang tinggi. Pada tahun 2015 tersebar di 21 Provinsi dari 34 Provinsi di Indonesia. Hal ini berarti angka perkawinan anak berdasarkan sebaran provinsi di seluruh Indonesia sudah mencapai angka yang mengkhawatirkan, yakni dengan jumlah persentase $61 \%$ (enam puluh satu persen) ${ }^{7}$.

Dampak yang dihasilkan dari pernikahan anak adalah peningkatan angka kemiskinan. Disamping itu, kematian ibu, kualitas kesehatan bayi yang dilahirkan dari perkawinan anak juga sangat memprihantikan. Jika terjadi perkawinan pada usia sekolah maka dapat dipastikan anak akan mengalami putus sekolah sehingga wajib belajar 12 tahun tak terpenuhi. Efek lain adalah terjadinya kekerasan seksual dan kekerasan rumah tangga yang semakin rentan terjadi sekaligus merenggut hak anak, merujuk Undangundang tentang Perlindungan Anak No 23 tahun 2002.

Mengacu pada rumusan yang terdapat pada Visi nasional pembangunan jangka panjang tentang pembangunan masyarakat adalah terciptanya manusia yang sehat, cerdas, produktif, dan berakhlak mulia dan masyarakat yang makin sejahtera dalam pembangunan yang berkelanjutan didorong oleh perekonomian yang makin maju, mandiri, dan merata di seluruh wilayah didukung oleh penyediaan infrastruktur yang memadai serta makin kokohnya kesatuan dan persatuan bangsa yang dijiwai oleh karakter yang tangguh dalam wadah Negara Kesatuan Republik Indonesia yang diselenggarakan dengan demokrasi [yang didasarkan pada nilai-nilai Pancasila] sebagai pedoman dalam kehidupan bermasyarakat, berbangsa, dan bernegara serta menjunjung tegaknya supremasi hukum ${ }^{8}$.

Tulisan ini hendak melihat sejauh mana rumusan Rencana Pembangunan Jangka Panjang Nasional dan Rencana Jangka Menengah Nasional dalam pembangunan tata hukum di Indonesia. serta melihat berbagai faktor yang menyertai pelaksanaan sehingga dapat diketahui berbagai faktor penghambat maupun faktor pendukung dari pembangunan hukum di Indonesia berkenaan dengan hukum adat yang berlaku.

Sebagai pengantar atas pembahasan dalam tulisan ini, maka penulis merumuskan dua rumusan masalah yang hendak didiskusikan sebagai berikut:

1. Apa indikator ideal dalam rumusan usia perkawinan adat?

\footnotetext{
${ }^{6}$ Asep Saepuddin Jahar dkk, Hukum Keluarga, Pidana \& Bisnis; Kajian Perundang- undangan Indonesia, Fikih dan Hukum Internasional (Jakarta: Kencana , 2013). 43

${ }^{7}$ Indry Octaviani, 'Koalisi Perempuan Indonesia', in Koalisi Perempuan Indonesia Untuk Keadilan dan Demokrasi < HYPERLINK "http://www.koalisiperempuan.or.id" http://www.koalisiperempuan.or.id > [accessed 18 November 2018]

${ }^{8}$ Badan Perencanaan Pembangunan Nasional, Visi dan Arah Pembangunan Jangka Panjang 2005

- 2025 (Jakarta : Kantor Menteri Negara Perencanaan Pemabangunan Nasional, 2007). 17
} 
2. Bagaimana co-existence hukum adat dan hukum nasional tentang usia perkawinan di Indonesia?

\section{Kerangka Teoritis}

\section{Konsep Usia dewasa}

Dewasa dalam bahasa belanda diartikan sebagai "volwas'sen", vol artinya penuh was'sen artinya tumbuh. Jadi volwas'en berarti "sudah tumbuh dengan penuh atau dewasa". Pengertian tersebut menunjukan bahwa orang dewasa adalah individu yang sudah menyelasaikan masa pertumbuhannya dan siap menerima kedudukan serta status baru dalam masyarakat bersama orang dewasa lainnya.

Pandangan tentang kedewasaan sebagaimana diungkapkan Vivian E. Hamilton ${ }^{10}$. Dalam perspektifnya dewasa adalah perpindahan masa remaja kepada masa dewasa yang akan memiliki beberapa konsekwensi baik secara sosial maupun hukum. Sebagaimana pernyataanya berikut:

Young people attaining adult legal status will lose the presumptive entitlement to parental support; lose the ability to disavow contracts due to age-based incapacity; gain the ability to participate in civic and political life; and, if convicted of a serious-enough criminal offense, become susceptible to sentences of life imprisonment or death ${ }^{11}$.

Secara biologis, wanita masuk dalam kategori siap dalam menjalankan fungsi reproduksi adalah mereka yang memasuki usia 20 tahun, sedangkan pria adalah berusia 25 tahun $^{12}$. Survey yang dilakukan pada beberapa negara menunjukkan bahwa pernikahan muda menjadi kecenderungan di berbagai negara berkembang. Berdasarkan United Nations Development Economic and Social Affairs (UNDESA), Indonesia merupakan negara ke-37 dengan jumlah pernikahan dini terbanyak di dunia ${ }^{13}$. Kondisi ini menunjukan bahwa kesadaran akan pendewasaan usia perkawinan menjadi penting dan mendesak untuk dilakukan demi tercapainya tujuan perlindungan bagi perempuan dan anak.

Perkawinan usia anak menyebabkan kehamilan dan persalinan dini, yang berhubungan dengan angka kematian yang tinggi dan keadaan tidak normal bagi ibu karena tubuh anak perempuan belum sepenuhnya matang untuk melahirkan ${ }^{14}$. Anak

\footnotetext{
${ }^{9}$ S. Wojowasito, Kamus Umum Belanda Indonesia, (Jakarta: PT. Ikhtiar Baru Van Hoves, 1990). hlm. 761

${ }^{10}$ Miftahus Sholehudin, 'Pembaharuan Usia Dewasa sebagai Syarat Perkawinan', Oktober 2018, hlm. 4

${ }^{11}$ Vivian E. Hamilton, Adulthood in Law and Culture, (Cambridge: Faculty Publications, 2016). hlm.57

${ }^{12}$ Pusat Data dan Informasi, 'Situasi Kesehatan Repoduksi Remaja', 29 Juni Dalam Rangka Hari Keluarga Nasional, 2015

${ }^{13}$ Ira Nurmala Intan Arimurti, Analisis Pengetahuan Perempuan Terhadap Perilaku Melakukan Pernikahan Usia Dini di Kecamatan Wonosari Bondowoso, The Indonesian Journal of Public Health, Volume 12 Nomor 1, 2017, hlm. 249.

${ }^{14}$ Centre for Reproductive Rights, Accountability for Child Marriage: Key U.N. Recommendations to Governments in South Asia on Reproductive Health and Sexual Violence (Fact Sheet), (New York: CFRR, 2013). hlm. 4
} 
perempuan usia 10-14 tahun memiliki risiko lima kali lebih besar untuk meninggal dalam kasus kehamilan dan persalinan daripada perempuan usia 20-24 tahun, dan secara global kematian yang disebabkan oleh kehamilan merupakan penyebab utama kematian anak perempuan usia 15-19 tahun $^{15}$.

Jika ditilik secara kuantitatif, hasil data yang dilansir oleh Riskesdas 2010 dengan melakukan penelitian pada perempuan dengan rentang usia 10 sampai 59 tahun. Menunjukan bahwa 4,8\% pernikahan di Indonesia dilakukan oleh perempuan dengan rentang usia 10 - 14 tahun. Pada level kedua, data menunjukan bahwa pernikahan dilakukan oleh perempuan dengan rentang usia 15 -19 tahun dengan besaran data 41,9\%. Pernikahan dengan jumlah paling rendah dilakukan oleh kelompok usia 35 tahun ke atas dengan persentase $0,6 \%{ }^{16}$.

\section{Usia Dewasa dalam Peraturan Perundang-Undangan}

KUHPerdata Indonesia mencantumkan bahwa disamping unsur umur dalam mengukur kedewasaan masih terdapat unsur lain dalam menentukan status dewasa yakni status pernikahan. Meski seseorang belum mencapai umur 21 tahun namun sudah menikah, maka ia termasuk dalam kategori dewasa. Konsep hukum perdata merumuskan bahwa pendewasaan seseorang dapat dilakukan dengan dua cara yakni, Pertama; pendewasaan penuh. Mereka yang termasuk dalam pendewasaan ini adalah anak yang telah mencapai umur 20 tahun yang diberi surat pendewasaan adalah Presiden (Menteri Kehakiman) dengan prosedur tertentu. Kedua, Pendewasaan terbatas. Mereka yang mendapatkan pendewasaan ini minimal berumur genap 18 tahun. Instansi yang memberikannya adalah Pengadilan Negeri di tempat tinggalnya ${ }^{17}$.

Batasan dewasa yang juga berlaku di Indonesia adalah sebagaimana tercantum dalam UU Nomor 1 Tahun 1974 tentang Perkawinan. Pada UU tersebut ditemukan tiga kriteria umur seseorang yang berhubungan dengan kedewasaan. Ketiga macam umur itu adalah:

a. Umur syarat kawin, yaitu pria 19 (sembilan belas) tahun dan wanita 16 (enam belas) tahun Pasal 7 ayat (1).

b. Umur izin kawin, mereka yang akan menikah di bawah umur 21 (dua puluh satu) tahun, harus ada izin kawin Pasal 6 ayat (2).

c. Umur dewasa, yaitu 18 (delapan belas) tahun atau telah kawin (Pasal 47 ayat (1), ayat (2) dan Pasal 50 ayat (1) dan ayat (2)).

Kriteria umur yang terdapat dalam UU No. 1 tahun 1974 diatas, sama dengan ketentuan Hukum Keluarga KUHPerdata. Buku I Bab tentang Hukum Keluarga KUHPerdata menjelaskan bahwa terdapat tiga kriteria umur:

\footnotetext{
15 Subdirektorat Statistik Rumah Tangga, Kemajuan yang Tertunda: Analisis Data Perkawinan Anak di Indonesia, (Jakarta: Badan Pusat Satistik Indonesia, 2016), hlm. 40

${ }^{16}$ Ira Nurmala Intan Arimurti, Analisis Pengetahuan Perempuan Terhadap Perilaku Melakukan Pernikahan Usia Dini di Kecamatan Wonosari Bondowoso, The Indonesian Journal of Public Health, Volume 1, 2017, hlm. 250

17 Sanawiah and Muhamad Zainul, Batasan Kedewasaan dan Kecakapan Hukum Pewasiat Menurut KHI dan KUHPerdata, Jurnal Hadratul Madaniyah, Volume 5 Issue 1, June 2018, hlm. 7
} 
a. Umur syarat kawin, yaitu bagi pria 18 (delapan belas) tahun dan bagi wanita 15 (lima belas) tahun Pasal 29 KUHPerdata.

b. Umur izin kawin, bagi mereka yang akan menikah yang belum berumur 30 (tiga puluh ) tahun diperlukan izin kawin Pasal 42 (1) KUHPerdata.

c. Umur dewasa, yaitu 21 (dua puluh satu) tahun atau telah kawin Pasal 330 KUHPerdata.

Undang-Undang No. 23 Tahun 2002 Tentang Perlindungan Anak dalam pasal 1 ayat 1 menyebutkan bahwa "anak adalah seseorang yang belum berumur 18 (delapan belas) tahun, termasuk anak dalam kandungan". Dalam undang-undang perlindungan anak yang membedakan antara anak dan dewasa hanyalah sebatas umur saja. Sebenarnya mendefinsikan anak atau belum dewasa itu menjadi begitu sulit ketika melihat batas umur anak atau batas dewasanya seseorang dalam peraturan perundang-undangan satu dan lainnya berbeda-beda.

Selain sulit secara definitif ketika menjelaskan usia dewasa bagi anak sebegaimana dijelaskan pada paragraf diatas, realitas ini menunjukan adanya ketidak seriusan pemerintah dalam merancang hukum yang komprehensif. Komprehensif maksudnya adalah adanya kesinambungan aturan perundang-undangan karena pada dasarnya pengaturan yang dilakukan adalah pada kelompok umur yang sama. Ketidak singkronan ini juga menjadikan target pembangunan yang dicanangkan pada masing-masing sektor juga kurang maksimal sebagaimana contoh tentang program wajardikdas, pendewasaan usia kawin dan berbagai program lainya.

\section{Pembahasan}

\section{Urgensi Hukum Adat}

Pembangunan hukum nasional sebagai langkah kongkrit dalam menata dan memperbaiki sistem hukum Indonesia tidak dapat melepaskan diri dari hukum adat. Asas hukum yang berasal dari hukum adat merupakan jiwa bangsa dan juga bagian penting dalam perkembangan hukum di Indonesia. Hilman Hadikususma menjelaskan dalam bukunya bahwa, hukum adat merupakan salah satu sumber penting untuk memperoleh bahan-bahan bagi pembangunan hukum nasional yang menuju kearah unifikasi hukum dan dilaksanakan melalui pembuatan peraturan perundang-undangan ${ }^{18}$.

Konsep dan perpsektif yang harus dibangun dalam menelaah posisi hukum adat menurut penulis ialah, hukum adat menempati posisi penting dalam proses pembangunan hukum nasional lebih spesifik lagi pada konteks unifikasi hukum namun tidak serta merta semuanya diterima. Meminjam istilah yang digunakan oleh Wayan Beni ${ }^{19}$ ialah meski hukum adat merupakan sumber hukum nasional bukan berarti semua materi hukum adat itu dapat dijadikan bahan atau sumber bahan hukum.

Aspek yang harus dikuasai dengan baik dan matang oleh para legislator ialah bagaimana nilai ideal dalam hukum adat tersebut dipahami secara substantif dan filosofis. Pemahaman yang hanya menangkap dari sisi luar saja juga dapat berakibat negatif karena

\footnotetext{
${ }^{18}$ Hilman Hadi Kusuma, Hukum Waris Adat, (Bandung: Citra Aditya Bakti, 2003), hlm. 1

${ }^{19}$ Wayan Beni dan Sagung Ngurah, Hukum Adat di Dalam Yurisprudensi Indonesia, (Denpasar: Surya Jaya, 1986), hlm. 1
} 
nilai dalam hukum adat haruslah dipahami secara koheren serta substantif. Contoh sederhana adalah ketika dalam hukum adat jawa dipersepsikan kedewasaan seorang anak ialah tatkala bisa memiliki tempat tinggal, maka seorang ahli hukum harus menggali sejauh mana korelasi usia kepemilikian rumah dengan berbagai konstelasi faktor lain seperti kondisi psikologis, biologis dan faktor lainya.

\section{Dewasa dalam Hukum Adat}

Membincang tentang kedewasaan, R. Soerojo Wignjodipoero ${ }^{20}$ mengemukakan bahwa dalam konsep hukum adat, yang dianggap cakap adalah seorang pria maupun wanita yang sudah dianggap dewasa. Kriteria untuk dewasa bukan hanya tentang umur melainkan dengan ciri-ciri tertentu, antara lain: a. kuwat gawe (sudah mampu bekerja dendiri) b. cakap mengurus harta benda dan lain-lain keperluan sendiri c. cakap untuk melakukan pergaulan dalam kehidupan masyarakat.

Dalam bukunya "Beginsellen en Stelsel van het Adatrecht" Ter Haar memaparkan bahwa kedewasaan dalam hukum adat memiliki ukuran yang beragam. Diantaranya terdapat pandangan yang mengungkpakan bahwa konteks kedewasaan diukur dari kepemilikan terhadap tempat tinggal.

According to the adat law of the small autonomous communities, the moment a pers; $n$ becomes full grown and marries, he or she departs from the family residence of the parents, and the married couple proceed to live as an independent family ${ }^{21}$.

Sedikit gambaran konsep kedewasaan dalam perspektif adat diatas tentu belum mewakili secara utuh tentang konsepsi kedewasaan seseorang. Namun sebagai pandangan umum dapat dipahami bahwa menentukan kedewasaan seseorang apalagi dalam aspek kesiapan melakukan perkawinan tidak cukup dilihat dari satu aspek saja. Aspek kesiapan dalam perkawinan bisa meliputi tentang kedewasaan, kesiapan psikologis, kesehatan jasmani, sosial, ekonomi dan faktor lain. Sehingga diharapkan arah pembangunan hukum nasional seputar perkawinan dibangun secara komprehensif dan tidak parsial sebagaimana yang terjadi saat ini.

\section{Isu Pembaharuan Hukum Anak Internasional}

Membincang dan membahas tentang perkawinan usia anak sesungguhnya telah lama menjadi isu internasional. Bahkan konsensus global tentang pentingnya penghapusan perkawinan dini, kawin paksa, dan perkawinan usia anak semakin mengemuka dalam beberapa tahun terakhir. Sekretaris Jenderal Perserikatan BangsaBangsa (PBB) pada tahun 2014 merekomendasikan adanya target khusus dalam Tujuan Pembangunan Berkelanjutan pasca 2015 untuk menghapus perkawinan usia anak ${ }^{22}$. Rekomendasi ini didukung oleh 116 negara anggota, termasuk Indonesia. Disamping itu,

\footnotetext{
${ }^{20}$ Soeroyo Wignjodipoero, Pengantar dan Asas-Asas Hukum Adat, (Jakarta: CV. Mas Agung, 1990), hlm. 104

${ }^{21}$ B. Ter Haar, Adat Law in Indonesia, (Djakarta: Bharatara, 1962). hlm. 163

${ }^{22}$ United Nations General Assembly, The Road to Dignity by 2030: Ending poverty, transforming all lives and protecting the planet-Synthesis report of the Secretary-General on the post-2015 sustainable development agenda (New York : United Nation, 2014).
} 
terdapat lebih dari 100 komitmen untuk menghapus perkawinan usia anak dan mutilasi genital perempuan dideklarasikan pada KTT Anak Perempuan yang diselenggarakan oleh UNICEF dan Pemerintah Inggris. Pada tahun 2014, Uni Afrika juga meluncurkan kampanye untuk menghapus perkawinan usia anak di afrika ${ }^{23}$.

Keterlibatan Indonesia dalam komitmen penghapusan perkainan anak diatas merupakan langkah yang baik dalam mengatasi problem nasional tentang anak di Indonesia. Namun dalam tataran kenyataanya Indonesia hingga saat ini masih saja memberlakukan program penanggulangan tersebut secara sporadis serta kurang komprehensif. Banyak sekali peraturan perundang-undangan yang mengatur tentang unsur kedewasaan masih berbeda-beda bahwa undang-undang perkawinan di Indonesia masih mengakomodir terjadinya perkawinan anak karena batasan usia menikah yang dibawah standart umur dewasa.

\section{Pembaharuan hukum anak dalam visi nasional}

Pada tahun 2007 pada saat pengesahan UU No. 7 tahun 2017 tentang Rencana Pembangunan Jangka Panjang Nasional, ${ }^{24}$ Indonesia telah mencanangkan 8 visi pembangunan nasional yang menjadi pedoman serta target pembangunan menyeluruh di Indonesia $^{25}$. Sebagaimana berikut:

1. Mewujudkan masyarakat berakhlak mulia, bermoral, beretika, berbudaya, dan beradab berdasarkan falsafah Pancasila adalah memperkuat jati diri dan karakter bangsa melalui pendidikan yang bertujuan membentuk manusia yang bertaqwa kepada Tuhan Yang Maha Esa, mematuhi aturan hukum, memelihara kerukunan internal dan antarumat beragama, melaksanakan interaksi antarbudaya, mengembangkan modal sosial, menerapkan nilai-nilai luhur budaya bangsa, dan memiliki kebanggaan sebagai bangsa Indonesia dalam rangka memantapkan landasan spiritual, moral, dan etika pembangunan bangsa.

2. Mewujudkan bangsa yang berdaya-saing adalah mengedepankan pembangunan sumber daya manusia berkualitas dan berdaya saing; meningkatkan penguasaan dan pemanfaatan iptek melalui penelitian, pengembangan, dan penerapan menuju inovasi secara berkelanjutan; membangun infrastruktur yang maju serta reformasi di bidang hukum dan aparatur negara; dan memperkuat perekonomian domestik berbasis keunggulan setiap wilayah menuju keunggulan kompetitif dengan membangun keterkaitan sistem produksi, distribusi, dan pelayanan termasuk pelayanan jasa dalam negeri.

3. Mewujudkan masyarakat demokratis berlandaskan hukum adalah memantapkan kelembagaan demokrasi yang lebih kokoh; memperkuat peran

\footnotetext{
${ }^{23}$ Thompson and Kennedy Minchew, 'The Summer of the Summit - Now what for child, early and forced marriage?', in Girls Not Brides < HYPERLINK "www.girlsnotbrides.org/summer-summitnow-child-early-forced-marriage" ww.girlsnotbrides.org/summer-summit-now-child-early${ }_{24}$ forced-marriage > [accessed 19 November 2018]

25 Biro Peraturan Perundang-undangan Bidang Perekonomian dan Industri , Lampiran UndangUndang Republik Indonesia No. 17 Tahun 2007 Tentang Rencana Pembangunan Jangka Panjang Nasional Tahun 2005-2025 (Jakarta : Sekretariat Negara RI , 2007), hlm. 39-40
} 
masyarakat sipil; memperkuat kualitas desentralisasi dan otonomi daerah; menjamin pengembangan media dan kebebasan media dalam mengomunikasikan kepentingan masyarakat; dan melakukan pembenahan struktur hukum dan meningkatkan budaya hukum dan menegakkan hukum secara adil, konsekuen, tidak diskriminatif, dan memihak pada rakyat kecil.

4. Mewujudkan Indonesia aman, damai, dan bersatu adalah membangun kekuatan TNI hingga melampui kekuatan esensial minimum serta disegani di kawasan regional dan internasional; memantapkan kemampuan dan meningkatkan profesionalisme Polri agar mampu melindungi dan mengayomi masyarakat; mencegah tindak kejahatan, dan menuntaskan tindak kriminalitas; membangun kapabilitas lembaga intelijen dan kontra- intelijen negara dalam penciptaan keamanan nasional; serta meningkatkan kesiapan komponen cadangan, komponen pendukung pertahanan dan kontribusi industri pertahanan nasional dalam sistem pertahanan semesta.

5. Mewujudkan pemerataan pembangunan dan berkeadilan adalah meningkatkan pembangunan daerah; mengurangi kesenjangan sosial secara menyeluruh, keberpihakan kepada masyarakat, kelompok dan wilayah/daerah yang masih lemah; menanggulangi kemiskinan dan pengangguran secara drastis; menyediakan akses yang sama bagi masyarakat terhadap berbagai pelayanan sosial serta sarana dan prasarana ekonomi; serta menghilangkan diskriminasi dalam berbagai aspek termasuk gender.

6. Mewujudkan Indonesia asri dan lestari adalah memperbaiki pengelolaan pelaksanaan pembangunan yang dapat menjaga keseimbangan antara pemanfaatan, keberlanjutan, keberadaan, dan kegunaan sumber daya alam dan lingkungan hidup dengan tetap menjaga fungsi, daya dukung, dan kenyamanan dalam kehidupan pada masa kini dan masa depan, melalui pemanfaatan ruang yang serasi antara penggunaan untuk permukiman, kegiatan sosial ekonomi, dan upaya konservasi; meningkatkan pemanfaatan ekonomi sumber daya alam dan lingkungan yang berkesinambungan; memperbaiki pengelolaan sumber daya alam dan lingkungan hidup untuk mendukung kualitas kehidupan; memberikan keindahan dan kenyamanan kehidupan; serta meningkatkan pemeliharaan dan pemanfaatan keanekaragaman hayati sebagai modal dasar pembangunan.

7. Mewujudkan Indonesia menjadi negara kepulauan yang mandiri, maju, kuat, dan berbasiskan kepentingan nasional adalah menumbuhkan wawasan bahari bagi masyarakat dan pemerintah agar pembangunan Indonesia berorientasi kelautan; meningkatkan kapasitas sumber daya manusia yang berwawasan kelautan melalui pengembangan ilmu pengetahuan dan teknologi kelautan; mengelola wilayah laut nasional untuk mempertahankan kedaulatan dan kemakmuran; dan membangun ekonomi kelautan secara terpadu dengan mengoptimalkan pemanfaatan sumber kekayaan laut secara berkelanjutan.

8. Mewujudkan Indonesia berperan penting dalam pergaulan dunia internasional adalah memantapkan diplomasi Indonesia dalam rangka memperjuangkan kepentingan nasional; melanjutkan komitmen Indonesia terhadap pembentukan identitas dan pemantapan integrasi internasional dan 
regional; dan mendorong kerja sama internasional, regional dan bilateral antarmasyarakat, antarkelompok, serta antarlembaga di berbagai bidang.

Pembangunan pemberdayaan perempuan dan anak diarahkan pada peningkatan kualitas hidup dan peran perempuan, kesejahteraan, dan perlindungan anak di berbagai bidang pembangunan; penurunan jumlah tindak kekerasan, eksploitasi, dan diskriminasi terhadap perempuan dan anak; serta penguatan kelembagaan dan jaringan pengarusutamaan gender dan anak di tingkat nasional dan daerah, termasuk ketersediaan data dan statistik gender ${ }^{26}$. Kerangka berfikir yang dibangun dalam perancangan rencana pembangunan jangka panjang sebagaimana dipaparkan dalam visi nasional diatas terlihat masih sangat abstrak dan visioner sehingga membutuhkan terjemahan dalam RPJMN.

Dalam proses pembentukan RPJMN tersebut terbentuklah Visi Indonesia tahun 2014 dalam RPJMN 2010-2014 yang mencanangkan "Terwujudnya Indonesia yang Sejahtera, Demokratis, dan Berkeadilan". Selama dua setengah tahun pelaksanaan RPJMN banyak hal telah dicapai melalui pembangunan di segala bidang untuk mendukung pencapaian visi Indonesia 2014 tersebut. Indikator-indikator pembangunan menunjukkan saat ini Indonesia lebih sejahtera dan demokratis dibandingkan kondisi awal pelaksanaan RPJMN 2010-2014. Namun demikian, terdapat indikasi kesenjangan yang sedikit melebar. Di samping itu, penegakan hukum dan pemberantasan korupsimasih menghadapi kendala dalam pencapaian targetnya.

Konsekuensinya adalah dalam sisa sekitar dua tahun pelaksanaan RPJMN ke depan perlu upaya yang sungguh-sungguh dari semua pihak untuk merumuskan kebijakan dan program pembangunan yang inklusif dan mendukung pemerataan pendapatan dan keadilan, disertai kerja keras dalam pelaksanaan program-program prioritas nasional.Dengan demikian keberhasilan dalam peningkatan kesejahteraan dan proses demokratisasi akan dinikmati oleh seluruh masyarakat Indonesia.

Untuk mengetahui pencapaian visi dan misi Presiden secara menyeluruh, dilakukan evaluasi dengan kerangka analisis seperti gambar dibawah ini. Dari kerangka analisis ini dapat dilihat bahwa pencapaian visi merupakan hasil dari pencapaian kinerja misi-misi yang mendukungnya. Pencapaian misi ditentukan dari hasil pencapaian kinerja agendaagenda, sedangkan pencapaian agenda merupakan resultan dari kinerja program-program kegiatan-kegiatan yang dikelompokkan ke dalam 14 prioritas nasional.

Terfokus pada masalah pendewasaan usia perkawinan sebagai bentuk perlindungan bagi anak dan mencegah terjadinya pernikahan anak, pemerintah telah merumuskan RPJMN dengan mencantumkan klausul pendewasaan usia perkawinan sebagaimana berikut:

Peningkatan pengetahuan dan pemahaman kesehatan reproduk- si bagi remaja melalui pendidikan dan sosialisasi mengenai pentingnya Wajib Belajar 12 tahun dalam rangka pendewasaan usia perkawinan, dan peningkatan intensitas layanan KB bagi pasangan usia muda guna mencegah kelahiran di usia remaja ${ }^{27}$

\footnotetext{
${ }^{26}$ Kantor Menteri Negara Perencanaan Pembangunan Nasional, Visi dan Arah Pembangunan Jangka Panjang 2005-2025, (Jakarta: BPPN, 2007), hlm. 48

${ }^{27}$ Kementerian Perencanaan Pembangunan Nasional, Rencana Pembangunan Jangka Menengan Nasional 2015-2019, (Jakarta: Badan Perencanaan Pembangunan Nasional, 2014), hlm. 66
} 
Upaya yang dilakukan dalam rumusan RPJMN diatas secara normatif sudah mulai masuk pada substansi dalam perlindungan terhadap perlindungan anak. Namun sebagai catatan kritis adalah belum adanya politik hukum yang memadahi dalam konteks pembangunan hukum yang berpihak pada perlindungan anak. Karena masalah utama dalam perkawinan anak adalah sinergitas antar lembaga dalam menjalankan dan memaksimalkan peran masing-masing. Sehingga seharusnya dalam bidang perkawinan menjadi mendesak untuk adanya perubahan pasal 7 ayat 1 tentang batasan usia menikah. Disisi lain bidang pendidikan harus terus berbenah dan berimprovisasi dalam meningkatkan capaian pembangunan bidang pendidikan sehingga visi pembangunan hukum yang berpihak dan melindungi anak dapat terealisir dengan baik.

Hubungannya dengan pembangunan hukum nasional, tidak lain adalah Sistem Hukum Pancasila, yang memperkuat kehidupan demokrasi dan memperkokoh tegaknya konstitusi di Negara Indonesia. Hingga saat ini, kita belum dapat berhasil sepenuhnya dalam membangun sistem hukum nasional yang bulat dan terpadu yang tumbuh dan berakar kuat pada cita hukum dan norma dasar Negara Pancasila. Sebagaimana pernah diucapkan oleh Satjipto Rahardjo bahwa pembangunan hukum selma ini belum sejalan dengan kebutuhan masyarakat dalam arti luas, pembangunan hukum nasional masih melenceng dari ideal seperti tercantum dalam UUD $1945^{28}$. Oleh karena itu, dalam kerangka perencanaan pembangunan hukum pada RPJMN ke depan harus memperhatikan sendi-sendi sosial budaya dikembangkan dalam pembentukan hukum, yang merupakan jati diri bangsa Indonesia.

Sesuai dengan target Peningkatan pengetahuan dan pemahaman kesehatan reproduksi bagi remaja melalui pendidikan dan sosialisasi mengenai pentingnya Wajib Belajar 12 tahun dalam rangka pendewasaan usia perkawinan, dan peningkatan intensitas layanan KB bagi pasangan usia muda guna mencegah kelahiran di usia remaja ${ }^{29 .}$

\section{Penutup}

\section{Simpulan}

Dari pembahasan yang telah dilakukan pada pembahasan diatas dapat disimpulkan dua padangan umum sebagaimana rumusan masalah yang telah dibuat. Jabaran dari rumusan masalah tersebut adalah:

Pertama, usia dewasa dalam perkawinan merupakan kriteria yang harus dipahami secara komprehensif baik aspek psikologis, budaya, hukum dan berbagai faktor lain yang harus saling dihubungkan. Korelasi antar bidang menjadi keharusan sehingga secara hukum perlu adanya aturan yang mendekati usia ideal pernikahan yakni 20 tahun sebagai hasil beberapa penelitian yang telah diapaparkan.

Kedua, pembangunan hukum yang telah dicanangkan dalam RPJP terlihat belum spesifik mengakomodir isu pendewasaan usia anak namun dalam RPJMN yang dicanangkan pada tahun berikutnya baik tahun 2010-2014 dan 2014-2019 terlihat isu

${ }^{28}$ Background Study: RPJMN 2010-2014, 2008, hlm. 63

${ }^{29}$ Kementerian Perencanaan Pembangunan Nasional, Rencana Pembangunan Jangka Menengah Nasional 2015-2019, (Jakarta: Badan Perencanaan Pembangunan Nasional, 2014), hlm. 66 
pendewasaan lebih didekati dengan baik dalam arti sudah muncul dalam pembahasan. Namun catatan yang perlu disampaikan adalah belum komprehensifnya pola pendewasaan yang dimaksud. Pendewasaan yang dijabarkan masih sebatas sosialisasi namun belum membangun sistem hukum yang baik dalam bentuk revisi perundangundangan yang ada seperti undang-undang perkawinan dan beberapa peraturan perundang-undangan lainhya.

\section{Saran}

Secara akademis saran yang penulis sampaikan dalam kajian artikel ini ialah, Pertama, harus disatukan pemahaman antara pembuat peraturan perundang-undangan tentang konsep kedewasaan. Penyatuan ini perlu dengan menggunakan pendekatan yang komprehensif seperti menggunakan pendekatan psikologi yang sudah menentukan rentang usia perkembangan seseorang dalam kedewasaan berfikir. Hal ini menjadi penting dilakukan mengingat dalam kajian hukum dan kajian sosiologi belum bisa ditentukanya kisaran umur dalam menentukan kedewasaan seseorang. Kedua, hukum adat sebagai jiwa bangsa harus selalu menjadi perhatian khusus merumuskan hukum nasional. Hal ini dilakukan agar peraturan perundang-undangan selalu hadir menjadi bagian yang utuh dalam masyarakat sehingga efektifitas yang diharapkan juga semakin mudah dipennuhi karena bukan merupakan aturan asing namun lahir dari jiwa bangsa itu sendiri.

\section{Daftar Pustaka}

\section{Buku :}

Asep Saepuddin Jahar dkk, Hukum Keluarga, Pidana \& Bisnis; Kajian Perundang- undangan Indonesia, Fikih dan Hukum Internasional, Jakarta: Kencana , 2013

Background Study: RPJMN 2010-2014, 2008

Badan Perencanaan Pembangunan Nasional, Visi dan Arah Pembangunan Jangka Panjang 2005 - 2025, Jakarta : Kantor Menteri Negara Perencanaan Pemabangunan Nasional, 2007.

Biro Peraturan Perundang-undangan Bidang Perekonomian dan Industri , Lampiran Undang-Undang Republik Indonesia No. 17 Tahun 2007 Tentang Rencana Pembangunan Jangka Panjang Nasional Tahun 2005-2025, Jakarta : Sekretariat Negara RI , 2007

Centre for Reproductive Rights, Accountability for Child Marriage: Key U.N. Recommendations to Governments in South Asia on Reproductive Health and Sexual Violence (Fact Sheet), New York: CFRR, 2013.

Chuzaimah T. Yanggo, Problematika Hukum Islam Kontemporer, Jakarta: Lembaga Studi Islam dan Kemasyarakatan, 2004.

Harry Blatterer, 'Contemporary Adulthood, Reconceptualizing an Uncontested Category', Sage Journal: Current Sociology, Volume 55, Issue 6, 2007

Hilman Hadi Kusuma, Hukum Waris Adat, Bandung: Citra Aditya Bakti, 2003 
Ira Nurmala Intan Arimurti, Analisis Pengetahuan Perempuan Terhadap Perilaku Melakukan Pernikahan Usia Dini di Kecamatan Wonosari Bondowoso, The Indonesian Journal of Public Health, Volume 12 Nomor 1, 2017

Ira Nurmala Intan Arimurti, Analisis Pengetahuan Perempuan Terhadap Perilaku Melakukan Pernikahan Usia Dini di Kecamatan Wonosari Bondowoso, The Indonesian Journal of Public Health, Volume 1, 2017

Kantor Menteri Negara Perencanaan Pembangunan Nasional, Visi dan Arah Pembangunan Jangka Panjang 2005-2025, Jakarta: BPPN, 2007

Kementerian Perencanaan Pembangunan Nasional, Rencana Pembangunan Jangka Menengan Nasional 2015-2019, Jakarta: Badan Perencanaan Pembangunan Nasional, 2014

Kementerian Perencanaan Pembangunan Nasional, Rencana Pembangunan Jangka Menengah Nasional 2015-2019, Jakarta: Badan Perencanaan Pembangunan Nasional, 2014

Mark Evenhuis and Jennifer Burn, Just Married, Just a Child: Child marriage in the Indo- Pacific region, Melbourne: Plan International Australia, 2014

Miftahus Sholehudin, 'Pembaharuan Usia Dewasa sebagai Syarat Perkawinan', Oktober 2018

Pusat Data dan Informasi, 'Situasi Kesehatan Repoduksi Remaja', 29 Juni Dalam Rangka Hari Keluarga Nasional , 2015

Sanawiah and Muhamad Zainul, Batasan Kedewasaan dan Kecakapan Hukum Pewasiat Menurut KHI dan KUHPerdata, Jurnal Hadratul Madaniyah, Volume 5 Issue 1, June 2018

Soeroyo Wignjodipoero, Pengantar dan Asas-Asas Hukum Adat, (Jakarta: CV. Mas Agung, 1990)

Subdirektorat Statistik Rumah Tangga, Kemajuan yang Tertunda: Analisis Data Perkawinan Anak di Indonesia, Jakarta: Badan Pusat Satistik Indonesia, 2016

Subdirektorat Statistik Rumah Tangga, Kemajuan yang Tertunda: Analisis Data Perkawinan Anak di Indonesia, Jakarta: Badan Pusat Satistik Indonesia, 2016

Ter Haar B., Adat Law in Indonesia, Djakarta: Bharatara, 1962.

Unicef Indonesia, Child Marriage in Indonesia, Jakarta: unicef media center, 2016

United Nations General Assembly, The Road to Dignity by 2030: Ending poverty, transforming all lives and protecting the planet-Synthesis report of the Secretary-General on the post-2015 sustainable development agenda, New York : United Nation, 2014.

Vivian E. Hamilton, Adulthood in Law and Culture, Cambridge: Faculty Publications, 2016.

Wayan Beni dan Sagung Ngurah, Hukum Adat di Dalam Yurisprudensi Indonesia, Denpasar: Surya Jaya, 1986

Wojowasito S., Kamus Umum Belanda Indonesia, Jakarta: PT. Ikhtiar Baru Van Hoves, 1990. 


\section{Internet :}

Indry Octaviani, 'Koalisi Perempuan Indonesia', in Koalisi Perempuan Indonesia Untuk Keadilan dan Demokrasi < HYPERLINK "http://www.koalisiperempuan.or.id" http://www.koalisiperempuan.or.id > [accessed 18 November 2018]

Thompson and Kennedy Minchew, 'The Summer of the Summit - Now what for child, early and forced marriage?', in Girls Not Brides < HYPERLINK "www.girlsnotbrides.org/summer-summit-now-child-early-forced-marriage" www.girlsnotbrides.org/summer-summit-now-child-early-forced-marriage > [accessed 19 November 2018] 